\title{
A Comparative Study of the Perception of Coastal Communities in Developing the Method of Distribution of Marine Zakat
}

\author{
Diki S Riwanto \\ Airlangga University
}

\begin{abstract}
Indonesia is one of the largest maritime countries in the world with enormous potential resources. One of the potential resources includes fishery resources which reached 6.4 million tons per year with the value of catch fisheries reaching more than USD 15 billion. Thus, the total foreign exchange of marine and fishery reached USD 71 million per year. But along with these facts, 83 percent of the coastal communities are still living in poverty. To overcome these problems, it is necessary to optimize zakat, because in reality, the implementation of zakat (in this case marine zakat) is not optimal. This study is aimed to identify and develop the distribution model of marine zakat based on local people's perception. In analyzing this research, the authors applied qualitative method through comparative study approach by using data collectiion technique in the form of in-depth interviews. The scope of this research targets the people who live in depok and gunung kidul beach, Yogyakarta. Through this research, the authors hope that the community can identify the development of the distribution model of marine zakat that can empower coastal communities and can motivate local people to be more productive and optimize the available amount of zakat.
\end{abstract}

Keywords: Islamic Economics, Marine Zakat, Empowerment, Coastal Community, Maritime

\section{INTRODUCTION}

Indonesia is a country with the largest number of islands and the largest sea in the world. In Indonesia, the ratio of the sea area is larger than the mainland, i.e. 5.8 million kilometers of ocean and 1.9 million kilometers of land (BPS, 2012). So it is not surprising to see why Indonesia got the status of an archipelagic country as has been declared during the Juanda Declaration. This is a very important factor in legal, political, economic, cultural, territorial integrity, the unity of the nation and marks the claims and efforts of international juridical recognition of the sovereign status of the island nation (Bappenas, 2014).

Indonesia has the potential of marine (both biological and nonbiological) resources in the economy that can be utilized for the welfare of the community. There are at least 11 sectors of the marine economy that can be developed, such as: (1) fisheries; aquaculture; (3) fishery industry; (4) marine biotechnology industry; (5) energy and mineral resources; (6) maritime tourism; (7) coastal forestry; (8) marine transportation; (9) maritime industry and services; (10) small island area resources, and 
(11) nonconventional natural resources (Dahuri, 2014). Utilization of this potential is quite important, considering that 65 percent of Indonesian people live in coastal areas. (BPS, 2013). It is also supported by Sweeden et al (2008), which says the understanding of the coastal economy contributes to the economy for several reasons, including: (1) highly productive coastal ecosystems and contributing large amounts of economic value to the coastal economy; (2) all countries in general, and the coastal economy in particular, has a complex system of ownership, markets, productive organizations, and governments that determine who receives economic benefits and who pay production costs.

Meanwhile, in terms of fishery resources, the Indonesian Marine Council (2017) said that Indonesia has the potential of fishery resources to the extent of 6.4 million tons per year with the number of captured fisheries reaching more than USD 15 billion. Thus, the total foreign exchange from marine and fishery reaches USD 71 Billion per year. In addition, based on data from BPS (2017), it is shown that the GDP growth in fisheries has always been higher than the National GDP and agriculture. However, while always increasing, by 2016, the contribution of fishery GDP to the national GDP only reached 2.27 percent. (see Chart 1).

Chart 1. GDP on Fisheries (Billion Rupiah), 2011-2017

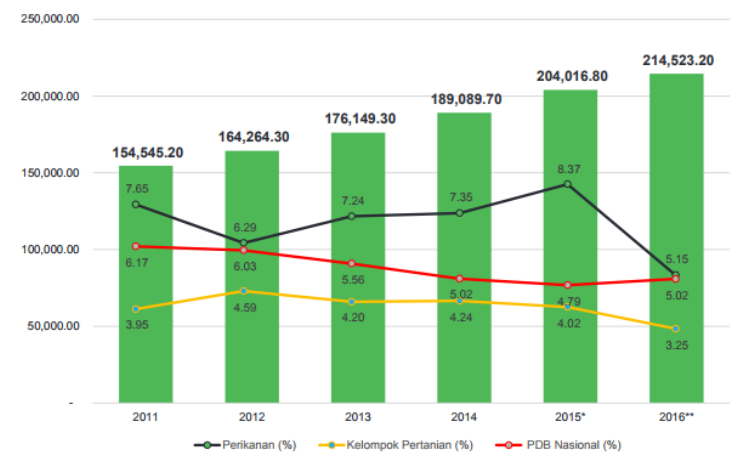

Source: Badan Pusat Statistik (2017)

* Provisional numbers
** Very provisional numbers

This potential is reinforced by the fact that aggregate increase in world economic growth is affected by the economic activity in the Asia Pacific region. According to the study of World \& Economic Forum, the most important variable of economic growth is the marine sector which is seen as Prime Mover. Consequently, it makes Indonesia as one of the potential countries for achieving higher economic growth, considering Indonesia is a maritime country located in the Asia Pacific region. Thus, it can be concluded that the welfare of coastal communities is of pivotal importance. However, as the facts stand, coastal communities are still categorized as poor. This is a solvable problem due to the large potential that should be utilized to reduce the number of poor people.

Poverty alleviation programs have long been undertaken by the Government of Indonesia, such as: Direct Cash Assistance (BLT), RASKIN, National Health Insurance (JAMKESNAS), School Operational Assistance (BOS), People's Business Credit (KUR), and National Community Empowerment Program (PNPM) which have been applied comprehensively. The government programs that are focused on coastal communities currently do not exist. However, poverty alleviation in villages and agriculture is different in coastal communities, because the number of fish obtained by fishermen can not be ascertained. But, as a matter of fact, the government is generalizing by not creating a specific program.

The existing programs such as the distribution of basic foods during the famine season as 
happened in the coast of Depok Yogyakarta still did not resolve the problem of poverty. This shows that poverty alleviation undertaken by the government needs to be evaluated, with a more technical approach to structural approaches, where the provision of facilities can support and facilitate coastal community activities. What is needed is a cultural approach that provides knowledge to improve human development (Kusumaningrum, 2013).

In Islam, according to Qardhawi in Al-Arif (2010), poverty alleviation can occur through optimizing the collection and distribution of zakat. Hence, zakat can be more efficient tool to resolve poverty in the economy. But in general, people's understanding of zakat is only about Zakat Fitrah and Zakat Maal. However, there are also other sources of zakat in accordance with the development in current modern economy. In addition to the zakat sources already mentioned, according to Qardhawi in Hafidhuddin (2002), there is also a zakat on marine products. Based on his views, what is in the sea and has an economic value must be subject to zakat. This way, the vast marine potential with relatively incomepoor coastal communities is expected to help in overcoming poverty. The existence of zakat provides one important source of fair finance.

Based on the facts that occur, there are still coastal communities who do not issue zakat on marine products. This is due to the lack of education of coastal communities about the zakat on these marine products. They need awareness on how the zakat will be implemented and how much nisab will be applied. Among the scholars also, there are still differences of opinion. Resultantly, the coastal communities do not know the criteria as to who is 'mustahiq' and who is 'muzakki'. In addition, there is lack of broad consensus, understanding and development related to the concept of zakat on marine products. Therefore, we want to analyze the perception of coastal communities in developing the method of distribution of zakat on marine products that can empower coastal communities and can motivate local people to be more productive and optimize the existence of this zakat.

\section{Research Question}

Based on the background description of the problem, the authors identify some key issues that will be discussed. Hence, the formulated questions are as follows:

1. Does the fishing community know about the existence of marine zakat?

2. Who is entitled to issue zakat?

3. How much is the potential of zakat that can be applied in Depok and Drini Beach, Yogyakarta?

4. Which distribution model of zakat on the marine product is appropriate?

\section{Target Research}

The targets to be achieved through this study are;

1. Identifing problems and components of marine development especially in Depok and Drini Beach, Yogyakarta.

2. The formation of thoughts for the concept of marine zakat and the basic ideas for the preparation of long-term zakat on marine products.

\section{LITERATURE REVIEW}

\section{Coastal communities}

Community can be defined as a local group of people which refers to citizens of a village, town, tribe or nation, both large and small 
groups who live together in such a way as to fulfill the main life interests (Soekanto, 1997). The coastal community is a group of people living in coastal areas, living together and meeting their needs from coastal resources. Communities living in cities or coastal settlements have socioeconomic characteristics closely related to the economic resources of the marine region. (Prianto, et al., 2005). Coastal communities that are primarily engaged in fishery business are generally still on the poverty line. They have no other job option, have low levels of education, and the majority of them are unaware of the preservation of natural resources and the environment (Lewaherilla 2002).

Problems faced by coastal communities, among others include: basic service facilities including physical infrastructures that are still limited; poorly maintained environmental conditions (lack of adequate health, clean inadequate water and sanitation, unsuitable housing conditions); community skills are limited to catching fish so that it does not support the diversification of activities; low population income; low education and public knowledge; and the economic activities of society are still traditional (Dahuri, 2016). Characteristics of coastal communities are dominated by fisheries. In general, if viewed from the economic point of view, the income level of coastal communities is still low so that they are on the poverty line. In addition, social conditions are characterized by low levels of education and the dependence of life on fisheries resources in the sea, thus making it less conducive to business diversification. Provision of basic service facilities such as roads, clean water, sanitation and garbage is still limited and insufficient. This causes the coastal community settlements to be unfit to live (slums) with high building density and low building quality.

\section{Coastal Characteristics}

Communities who live in coastal areas have unique characteristics that make them different from those living in rural, urban or mountain areas. These characteristics are closely related to the nature of the business of fisheries. They are equipped with the ability to catch, cultivate and make efforts to earn income from the marine wealth.

Coastal communities are generally pluralistic societies with high social life, meaning that the structure of coastal society is a combination of the characteristics of urban (plural) and rural (high social life). On the one hand, they are guided by traditional rural culture, but on the other, they have to accept the flow of city tourists who travel to the coastal areas or city traders who want to buy fishing marine products. This makes the structure of coastal communities very plural (Wahyudi, 2003). As for factors affecting fisheries business such as environment, season and market, the characteristics of coastal communities are also influenced by these factors.

\section{Reliance on the Environment}

Coastal communities are especially vulnerable to environmental factors, especially to water problems. Since the main income source depends on utilizing sea products, water conditions become the most important factor for income levels. If the water is polluted due to industrial waste or anything else, it will affect the quantity and quality of the catch of fishermen, in addition to the pollution that can damage the marine ecosystem. So if such a trend continues, it will have negative effects on the coastal community itself. Another problem 
that hampers fishermen related to the environment is the use of technological factors. If their environment is still traditional, then the technology used to catch the fish is also traditional.

\section{Reliance on Season}

Another important factor for coastal communities, especially for the fishermen, is the season. They are very much dependent on the seasons, especially the small fishermen who depend on the wind direction. Fishermen with large boats depend on seasons where the season determines when big waves will appear. Even if they use engine power, it is risky to face big waves. This condition has a great impact on the social condition of coastal communities in general and the fishermen in particular. Fishermen may earn a lot of income during the fishing season, but the fishermen will experience distress in the necessities of life when big waves season comes. That is dangerous for fishermen if they are catching fish in the sea and it affects the catch of fish that they obtain. In general, the income of the fishermen is fluctuating because the fishermen are unable to predict how much they will catch. Sometimes they get a large number of catches, but it could be possible that on the next day, they get nothing. For example, the coastal communities living in the southern coastal areas of Java with relatively large waves, can not go to sea every day. They can only go at times when the waves are not big.

\section{Reliance on the market}

The next factor is the market, which also has an important role in the life of coastal communities, including both fishermen and fish sellers. Unlike farmers where their crops can survive for long periods of time, the marine products have a short lifespan. So when harvested, fishermen must immediately look to sell the fish. When the fish catch is abundant, the fishermen are not immediately happy because of the law of demand and supply. If the number of goods supplied increases, the price becomes cheaper. Besides, the intense competition among fishermen who also sell the catch also causes fluctuations in fish market prices.

\section{Zakat}

The definition of zakat according to the UU No 38 of 1999, is 'the obligation of Indonesian Muslims who are categorized as financially capable to pay a prescribed amount of wealth from their existing stock of wealth. Zakat is a potential source of funds in realizing the welfare of the community. In addition, zakat is the realization of religion in the realization of justice for all people of Indonesia by paying attention to the poor. As an effort to effectively utilize this institution, the management system of zakat needs to be improved so that the implementation of zakat becomes more effective, efficient and accountable.

Zakat becomes the obligation for individuals who have wealth reaching nisab (muzakki). Then, it is distributed to eight groups of beneficiaries of zakat (mustahik). If viewed in terms of language, zakat has the meaning of blessing, growth, and holyness (Ascarya, 2008). In general, people's understanding of zakat is only restricted to Zakat Fitrah and Zakat Maal. Though there are also other sources of zakat in accordance with the development of the modern economy. These sources include: zakah on profession, zakah on the company, zakah on commercial paper, zakah on currency trading, zakah on traded livestock, zakah on 
animals, zakah on property investment, zakah on sharia insurance, zakat of orchid plant, ornamental fish, bird swallow, and modern household accessories (Hafidhuddin, 2002). In addition to the zakat sources mentioned above, according to the research of Yusuf Al Qardhawi, there are also zakat marine products. As per his views, what is in the sea and that has an economic value must be issued zakat. Resultantly, the vast marine potential with income-poor coastal communities is expected to help in resolving poverty since zakat is one source of fair finance.

\section{Zakat Marine Products}

Along with the development of technology and science, the level of modern economic growth led to the existence of various types of new assets that have greater potential and productivity. Although such property is explicitly not mentioned in the Qur'an and Hadith, but it is not an exception (Tahsin) that the types of property not mentioned in the Qur'an and Hadiths are not obligated to issue zakat (Qadir, 2002). As the Zakah of marine product which is not mentioned explicitly in the Qur'an, then based on the previous explanation, it must still be subject to zakat. Because the marine product is one of the wealth that is developing now and is a basic necessity of daily life for coastal communities and has economic value. Thus, zakat on marine product must be subject to zakat. In accordance with qiyas, zakat application on new assets and wealth would be equivalent to the type of zakat on wealth which were mentioned in the textual sources. It has also been exposed in Q.S At-Taubah: 103 that every valuable source of wealth we have is subject to zakat.

"Take alms of their wealth, wherewith thou mayst purify them and mayst make them grow, and pray for them. Lo! thy prayer is an assuagement for them. Allah is Hearer, Knower"'(QS At Taubah; 103)

And the zakat is taken from the good and lawful property, it is contained in Q.S Al-Baqarah: 267.

"Allah disdaineth not to coin the similitude even of a gnat. Those who believe know that it is the truth from their Lord; but those who disbelieve say: What doth Allah wish (to teach) by such a similitude? He misleadeth many thereby, and He guideth many thereby; and $\mathrm{He}$ misleadeth thereby only miscreants" (QS Al Baqarah; 26)

But related to the obligation of Zakah on sea products, there are differences of opinion among Ulama, such as:

\section{Opinion on the obligation of marine zakat}

What has been said about amber and ornaments derived from the sea such as pearls and others also apply to fish caught by fishermen. The marine products have enormous potential to generate enormous amounts of money, when worked by large companies with modern equipment. Therefore it is very unusual if fish are not subject to the obligation to pay zakat which is analogous to mining, agriculture and others (Al Qardhawi 1996).

Abu Ubaid narrated it from Yunus bin Ubaid, "Umar sent a letter to his officers in Oman so he would not collect anything from a fish that was less than 200 dirhams. If it is worth 200 dirhams, that is big nisab money, then it must be levied zakat. It was also narrated from the 
source of Ahmad. According to the Imami mazdhab, the zakat of fish is 20 percent because they see it as the ghanimah ( $\mathrm{Al}$ Qardhawi, 1996).

There are two views of the high priest that is, Malik and Shafi'i, which reinforce the proposal, that is, the amount of Zakat should be different based on the heavy income of the work, the burden, the amount obtained, and what is obtained: the zakat can be 20 percent and 2.5 percent.

\section{Opinions That Do Not Require Zakah Marine Product}

According to research conducted by Yusuf AL Qrdhawi on marine results contained in the book of Zakat Law (comparative study on the Status and philosophy of zakat based on Quran and Hadith), among others, there are differences of opinion about the law of goods exploited from the sea such as pearls and marhan, and perfume like amber supposedly one piece can weigh 100 misqal. According to Abu Hanifah, Hasan bin Salih and the mahzab of the Zaidiah Syiah, are not subject to anything. As Ibn Abbas argues, narrated by Ibn Syaibah and others that amber is not a treasure but is something produced in the sea, and therefore it is not imposed on anything (Al Qardhawi, 1996).

\section{Implementation of Zakat as a Public Financial Instrument}

According to Mannan, the element in Islamic socialism is zakat. So the zakat is said to be the financial axis of the Islamic state. Zakat is different from a tax. The difference is in the recipients of zakat which as established in the Qur'an and also the burden of zakat is fixed. Mannan also stated that the existence of zakat does not cause a negative impact on the motivation of a Muslim to work, because the fact zakat can encourage someone to work hard. This is because basically no one wants to be the recipient of zakat, thus encouraging someone to work harder. Sayyid Mahmud Taleghani views zakat as an effort to maintain cooperation and form of fair distribution in public demand, in addition to religious obligations (Haneef, 2010). In its implementation, zakat has a dominant effect in people's life, such as:

a. Production

The impact of zakat will lead to a potential new remainder which will further increase the aggregate demand that will ultimately encourage producers to increase production to meet existing demand.

b. Investigation

In addition to the impacts described above, increasing production will make the company to increase its investment.

c. Jobs

Given the increase in investment. it can make a bigger increase in production which means it will expand employment.

d. Growth

Increased aggregate demand makes an increase in investment, thereby promoting economic growth.

e. Social gap

Zakat plays an important role in the process of income distribution which will lead to a reduction in social inequality.

\section{RESEARCH METHODOLOGY}

\section{Type of research}

Type of research in this research is a case study by comparing the potential of zakat between Depok Beach, Bantul with Drini Beach, Gunung Kidul. The objective is to 
examine whether the income of the fishermen has potential to be subject to zakat or not.

\section{Character of research}

This study uses descriptive and qualitative methods. Data is obtained through observation (field research), interviews, and literature study.

\section{Objects of Research}

The objects of this research are:

a. Depok Beach, Parangtritis Village, Kretek District, Bantul Regency, Yogyakarta Province.

b. Drini Beach, Banjarejo Village, Tanjungsari District, Gunung Kidul Regency, Yogyakarta Province.

\section{Data collection techniques}

Data collection techniques used in this study are as follows:

a. Direct observation techniques, researchers reside with the object under study and directly make observations to the object under study (the fishermen and the income).

b. In-depth interview technique where the researcher conducts direct interviews of fishermen, $t a$ 'mir, and traders.

c. Documentation and literature techniques.

\section{DISCUSSION}

\section{Objects of Research}

\section{Depok Beach}

Depok beach apart from being a tourist area, is also a coastal fishing area. Usually, people go there other than a tourist destination, but also to buy fish from the fishermen who comes to fish. The buying and selling of fish there happens through the fish auction, as well as through the direct sale and purchase transactions conducted at the seaside. Depok beach majority community works as fishermen, but not the fisherman, but as helpers to fisherman. The main fishermen there mostly come from cilacap since the local people are still afraid to fight the waves which are quite big. Besides fishermen, the coastal communities in Depok also work as traders and farmers. So that when the tide is high, the people there work as farmers ad switch professions.

For the coastal communities in Depok beach, the sailing day begins at $05.00-11.00 \mathrm{WIB}$, but in January-June they do not sail because in these months, the tide iss high so that the fishermen do not dare to look for fish. That is why; it is referred to as the lean season. The fish season lasts from June to September where the number of fish catches rises. There can be variation in the catch. The maximum catches of fish can reach $50 \mathrm{~kg}$ of fish or $\mathrm{Rp}$ $15,000,000$ in one arrest and even more than this. On the other hand, the minimal catches reach an average of $\mathrm{Rp} 200,000$ or even lower.

Obtained from an interview with Mr. Soekamto on July 29, 2017 , one of the fishermen in the local area, it was revealed that the fishermen use vessels belonging to the skipper, so that the fishermen who do not have a ship could use the boat skipper. After deducting operating expenses from the catches, the net income is distributed through revenue sharing between fishermen and skipper with the percentage of 50:50.

Types of fish caught include Depok coast snapper, tuna, pomfret, layur, crabs, lobsters, rays, grouper, shark, squid, and small shark species. On the beach, there are fish markets. People are engaged in sea fishing, sea trade, and marine processing services. To meet the 
demand, the required quantities are usually supplied from cilacap.

In Depok beach management operations, the cooperative is one of the institutions that have an important role in developing coastal management. The cooperative is a form of credit union who rent out stalls at the beach area. The rental price of every shop is different. Food shop rental price is around $\mathrm{Rp} 250,000$ per annum, while garments shops rental price reaches $\mathrm{Rp} 300,000$ per year. The system of withdrawal is made by officers of Cooperatives in April, but due to the mechanism of the cooperative management upholding the principle of Amil, then before the withdrawal is made, prior notice of one week is given in order to prepare in advance. Thus, it can be seen that the role of Cooperatives is quite large.

Informants say that the sellers and fishermen around the coast Depok are residents of territory around the place. The sellers take days off when they are on vacation. It is because there are only a few visitors at TPI. So during a normal day, only very few sellers are selling because they focus on the tourists who visit, but it is undeniable that the traders also become an important part of selling marine products.

\section{Drini Beach}

Coastal communities in Gunung Kidul district Drini beach represent a society that mostly consist of Brazilians. Other than fishermen, there are merchants as well since Drini Beach is an area that is pretty crowded for tourism. The virtue of Drini beach is that it is a beach for fishermen as well as a beach for tourism in contrast to most of the beaches which are located along the coastline of the mountain Kidul district. These qualities make beach Drini a hot spot to visit not only for sightseeing, but also to enjoy fresh fish catches from the fishermen who are there.
Nonetheless, Drini Beach is still not able to support the economy of the people over there as the majority of people still live in poverty. It is observed in this study that coastal communities, especially the fishermen Drini committee still has no specialized institutions such as Cooperatives or BMT to provide financing to support the productivity of the fishermen. The fishermen still do business on their own without any individual group or organization that can facilitate operation of fishermen fishing on the coast Depok Bantul.

In interviews conducted with three fishermen, the researcher came to know that for each vessel involved in the fishing, income may reach 500 thousand to three million rupiahs depending on the season and huge waves at sea. During the hurricane season and when there are high waves, even the fishermen on the beach Drini do not dare to go to sea. This negatively impacts the economy of the fishermen there. It usually occurs in January and March. This period is the most difficult time for fishermen because they play loose their livelihood. So at that time, the fishing activities of vessels only perform repairs and fishermen go to the town to be a seasonal construction worker.

Types of fish that is usually acquired by fishermen include skipjack tuna, rays, appeal, pomfret, layur, mackerel, squid, crab and lobsters. Their price and demand in the market is quite high. One of the differences between the fishermen in Depok and Drini beach is the revenue management. Fishing at Drini Beach involves operating costs such as fuel, coffee and cigarettes. Revenue results at sea will be further reduced due to high operating costs. In profit sharing, 
the portion of the ship owner is always greater. A typical profit sharing portion calculation by the fishermen of Drini Beach is illustrated in Table 1. below:

Table 1.

Calculation of Servings Sharing at Drini Beach

\begin{tabular}{ccc}
\hline $\begin{array}{c}\text { Number of } \\
\text { Fishermen In } \\
\text { Boat }\end{array}$ & Shipowners (1) & The crew \\
\hline 1 & 75 percent & $25 \%$ \\
2 & 50 percent & $25 \%+25 \%$ \\
3 & 40 percent & $20 \%+20 \%$ \\
& & $20 \%$ \\
\hline
\end{tabular}

Source: Author (2017)

In connection with the charity, marine fishermen are still not aware of any such charity. They spend only tithes which are issued each year. From this information, it can be seen that the fishermen still do not know the importance of zakat potential of marine products to support their welfare.

In addition to interviewing the fishermen, the researcher also conducted interviews of one of the existing traders at Drini shore. The traders sell fish, shrimp, crab, squid and seaweed obtained from the shore. Fishermen catch fish and trade with the tourists who visit the place. The selling price is relatively cheap compared to the market price since the fish are directly obtained from the fishermen without any intermediary.

Revenue traders at Drini are uncertain of their future income as it depends on whether there is a working day and if the weather and season is favorable. Most traders do not sell every day, but only on weekends, holidays and the national days. Some traders do not stay permanently in the region of Drini beach. Merchants who sell every day are usually traders who have a house and have settled permanently in the area. On holidays, people can earn Rp 500,000 to Rp 1 million, while the average day only gets Rp 100,000 and even no buyers at all.

Most traders live below the poverty line due to the lack of income they earn when compared to the expenditure they should spend in order to continue with their daily lives. The absence of Cooperatives or other institutions that can provide financing to developing businesses and empowering traders is a significant constraint.

Other parties that were interviewed in this study include the ta'mir mosque clerics as well as Amil in charge of collecting and allocating zakat funds. These interviews revealed information that is linked to the problem of zakat mobilization. The fishermen still do not have awareness about zakat on marine products. Even in the mosque, there is no charity fund raising activity because most fishermen are in fact not native to the coastal regions. They give to charity in a mosque in the district or the village where they live. This proves that the zakat potential of marine products is still not implemented as well as it should have been.

\section{Analysis of Results}

Based on the results of research on the Depok Beach and Drini Beach, Gunung Kidul, the authors make the classification scheme of fishermen income belonging to muzakki and mustahik described in Figure 1. below. 
deducted, it will give rise to net income. The net income equally and distributed to the crew. If the net income has been in the share of 200 dirhams or worth approximately $\mathrm{Rp}$ 600,000 (1 dirham $=$ Rp 3,000). So according to the opinion of mazhab Imam Malik and Syafi'i, it is subject to zakat by 20 percent which is analogous to the result of mine, agriculture and others.

In the second category, the ship is not private property. The vessel is in the form of a loan obtained from a skipper who has a stake in net income when profit sharing is done between the

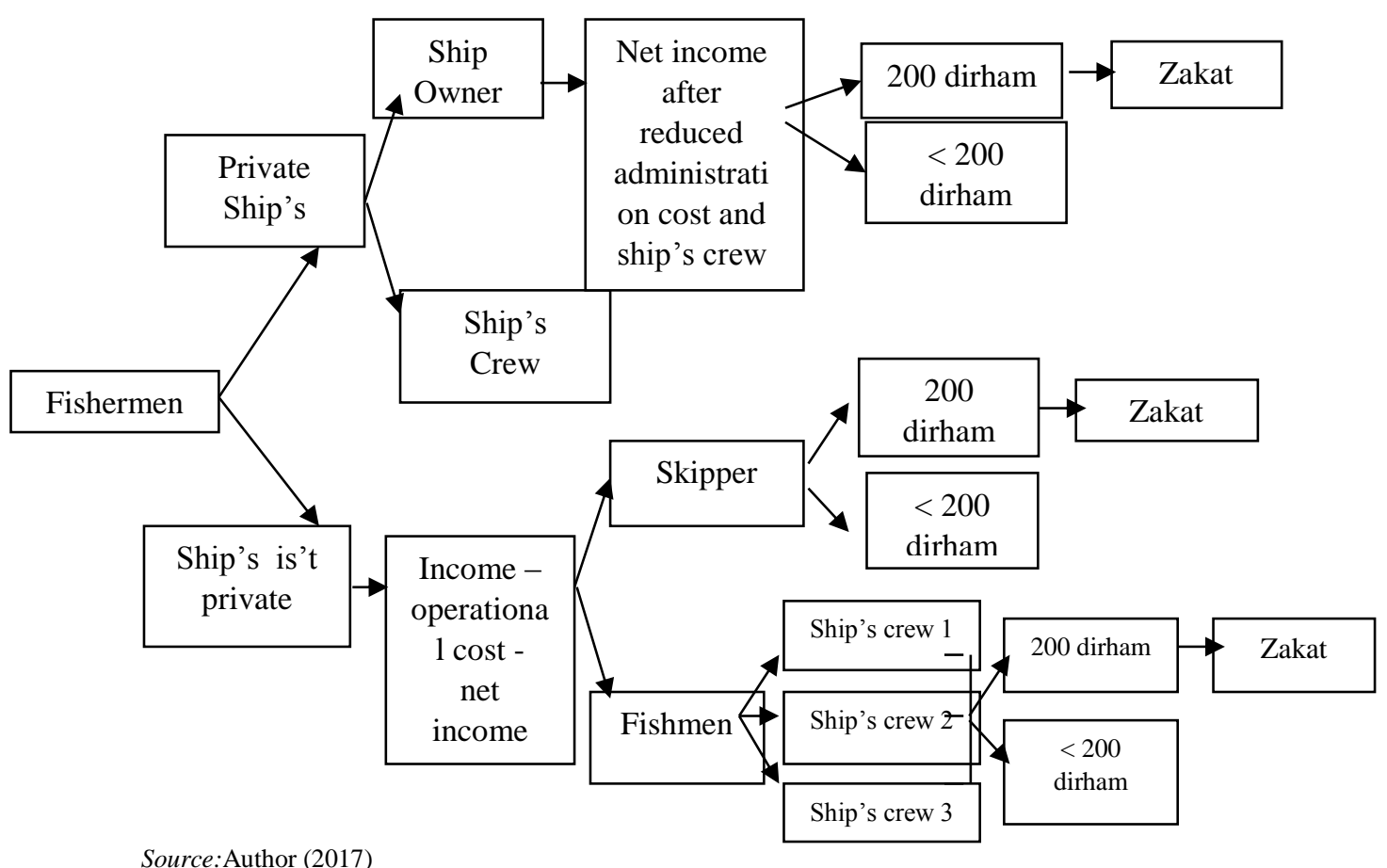

Source:Author (2017)

shipowner and the borrower of the vessel with the percentage of profit sharing being 50:50. As many as 50 percent is distributed to the ship's borrowers. It will be distributed to a number of fishermen who sailed. The average number of fishermen in a single ship comprises three fishermen. So, if the net income that has been distributed either from the side of the fisherman or skipper, reaches 200 dirhams or worth requires an operational cost of $\mathrm{Rp}$ 200,000). When operating costs are 
approximately $\mathrm{Rp} 600,000$, then there is obligation to pay zakat.

From the classification that has been described, an outline can be drawn as to know that muzakki having a net income worth 200 dirhams is subject to zakat. As per the data classification above, it is mostly found that the owners of ships and skipper have this much net income. A mustahik is a person that has a net income of fewer than 200 dirhams.

\section{Distribution of Zakat for Model Development}

Now, it is already known who mustahiq is and who is classified as muzakki. It will now be easier to distribute zakat, because of the data obtained as per this outline. The muzakki is a skipper, while the mustahiq are fishermen (who still participate with skipper). So, skipper and private shipowners are obliged to pay zakat. The zakat distribution models have to be efficient for the productive distribution of zakat. One approach is that the charity will be made in venture capital to the fishermen who qualify.

Business zakat distribution is with local institutions (ta'mir). The ta'mir organizations are Amil zakat institutions which specifically contribute to the survey of muzakki and mustahik for charity, counting the number of needy, determining the distribution issue and deciding whether the zakat will be given directly (consumer) or as venture capital (productive). After distributing zakat, Amil is also obliged to foster social mobility through economic growth in a productive society.

In developing this model, researchers conceive a model of the collection and distribution of zakat funds on marine products named as AGE (Amal Fisherman Nets). The reason for the name is that it gives a popular name for the coastal people, especially fishermen. Because in operations, it is needed to build trust among bosses and owners of private boats when issuing zakat on sea produce. It is important to socialize the importance of paying zakat on marine products as well as highlighting its potential in the management of zakat. This is the main reason why the researchers chose ta'mir as an institution to manage and administer the zakat proceeds rather than forming new institutions. The advantages of forming a special body under the auspices of ta'mir is to collect, manage and distribute effectively.

- Every village must have a mosque and ta'mir as managers.

- Ta'mir is the most trusted person in addition to being ta'mir society because they also are answering all the problems of the religious scholars.

- Ta'mir as alms collectors have the right to collect the zakat funds, so ta'mir is a better staffed agency specialized in the management of zakat on marine products.

- With ta'mir as the administrator, the charity funds will be optimized due to the transparency of zakat that can be published in the mosque but it is a more central mosque as community activities. The age scheme (charity nets of fishermen) are as follows:

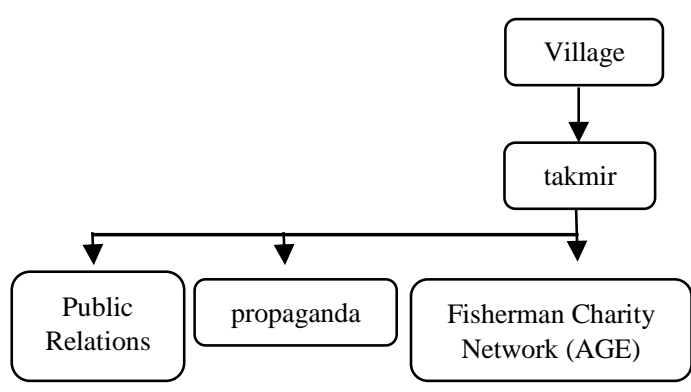

Source: Author (2017) ational Structure Ta'mir 
Charity nets of fishermen in the development of the model in this research have several programs related to the collection, management and distribution of zakat funds on marine products supplied by fishermen as muzakki. Following tasks are a part of AGE:

a. Collecting data from the fishermen to ascertain who becomes muzakki and who are entitled to be mustahiq.

b. Doing charity fund raising from muzakki including the skipper and private ship owners who are required to fulfill zakat obligation on seafood.

c. Manage and be responsible for such charity funds and have more transparency for the entire community in the form of reports and information placed on the boards affixed in mosque.

d. Doing the distribution of zakat funds to the mustahiq in the form of venture capital assistance or development of small fishing businesses.

Hopefully, by the involvement of specialized agency in the institutionalization of zakat, the potential of zakat collectible on marine products can be enhanced and be used to improve the welfare of coastal communities, especially the fishermen.

\section{CONCLUSION}

Zakat on marine product is one kind of zakat that is not taken into account by the fishermen, due to lack of knowledge and lack of socialization from related institutions. The results of this research show that there is no significant collection of zakat on marine products. So, in this situation, researchers are encouraged to make a model of marine zakat distribution. In this case, we can cluster who is categorized as mustahiq or muzakki. In general, mustahiq are the fishermen whose status is still working alongside the skipper or the small fishermen who are still living below the poverty line, and the muzakki is the skipper who already owns several ships or private boat owners whose fish catch has reached nishab.

The authors provide solutions in the form of development of collection and distribution of zakat on seafood mobilized and distributed through zakat institutions. It is on this matter that the author makes a model for the distribution of zakat on seafood that will be collected by an organization called "Jaring Amal Nelayan" (JAMAN). The organization is managed by ta'mir local mosque. It is hoped that due to the involvement of JAMAN, the application of zakat on marine products can be coordinated. It is vital because zakat itself has a dominant effect in social life and economic activities, such as production, investment and opening job fields. All of this can aid in an effort to overcome social disparity.

\section{RECOMMENDATION}

After conducting research and making conclusions on the perception of coastal communities in developing the distribution model of marine zakat, there are several suggestions submitted by the authors including, among others:

1. It needs support from the government and the community about the importance of zakat on marine product so that it can be applied.

2. For institutions that have the authority as collectors of zakat, there is need for contribution in the rural areas 
rather than only in urban areas.

3. The need for socialization in both the mosque and directly in the community regarding the importance of the zakat on the seafood and marine produce.

\section{REFERENCES}

Abdurrachman, Qadir. (1998). Zakat Dalam Dimensi Mahdhah Dan Sosial. Jakarta: PT Raja Grafindo Persada.

Ascarya. (2007). Akad dan Produk Bank Indonesia. Jakarta: Bank Indonesia.

Badan Perencanaan Pembangunan Nasional. (2014) Konsep Mainstream Ocean Policy Kedalam Pembangunan Nasional. Jakarta.

Hafidhuddin, Didin. (1998). Zakat Infak Sedekah. Jakarta: Gema Insani Press. (2002). Zakat Dalam

Perekonomian Modern. Jakarta: Gema Insani Press.

Haneef, Mohamed Aslem. (2010). Pemikiran Ekonomi Islam Kontemporer: Analisis Komparatif Terpilih. Jakarta: Rajawali Pers.

Huda, Nur. et al. (2008). Ekonomi Makro Islam. Jakarta: Prenada Media Grup.

Karim, A. Adiwarman. (2007) Ekonomi Makro Islam. Jakarta: PT Raja Grafindo Persada.

Kusumaningrum, Arta. (2013) 'Kebijakan Pembangunan Dalam Pengentasan Kemiskinanmasyarakat

Pesisir(Studi Kasus pada Masyarakat Pesisir diKabupaten Purworejo, Jawa Tengah)', Jurnal Sosial Ekonomi dan Kebijakan Pertanian., 2 (1).

Kusumastanto, Tridoyo. (2003) Pemberdayaan Sumber Daya Kelautan, Perikanan dan Perhubungan Laut dalam Abad XXI. Yogyakarta.

Nawawi, Ahmad. (2013). 'Partisipasi
Masyarakat dalam Pengelolaan Wisata Pantai Depok di Desa Kretek Parangtritis', Jurnal Nasional Pariwisata, 5 (2): 103-9.

Prianto, Eddy. (2005) 'Fenomena Aktual Tema Doktoral Arsitektur dan Perkotaan', in. Semarang: Badan Penerbit Universitas Diponegoro.

Qardawi, Yusuf. (1996). Hukum Zakat. Jakarta: Litera Antar Nusa.

Rianto, Nur. (2010). Teori Makro Ekonomi Islam. Bandung: Alfabeta.

Sutrisno, Endang. 'Implementasi Pengelolaan Sumber Daya Pesisir Berbasis Pengelolaan Wilayah Pesisir Secara Terpadu untuk Kesejahteraan Nelayan', jurnal Dinamika Hukum, 14 (1): 1-12.

Sweeden, Paula., Batker Deve., RadtkeHans., Boumans Roelof., Willer Chuck, (2008) An Ecological Economics Approach to Understanding Oregon's Coastal Economy and Environment, Coast Range Association. New York. Available at: http://www.coastrange.org/Co astal EconomicsReport.pdf.

Wahyudin, Y. (2003) 'Sistem Sosial Ekonomi dan Budaya Masyarakat Pesisir', Researchgate, 1-26.

Winata, Adi. and Ernik Yuliana, (2010) 'Peran Masyarakat Pesisir Dalam Penerapan Strategi Konservasi Sumberdaya Laut (Kasus Di Kelurahan Palabuhanratu, Kecamatan Palabuhanratu, Kabupaten Sukabumi)', Jurnal Matematika, Sains, dan Teknologi, 11(2), pp. 
$122-132$.

Witarsa (2015) 'Model Pengembangan

Ekonomi Masyarakat Pesisir

Berbasis Co-Management

Sumberdaya Perikanan Di

Kabupaten Pontianak', Jurnal

Economia, 11(1).

Diki S Riwanto

Airlangga University

diki.s.riwanto123@gmail.com 